\title{
The profiling of cable modem broadband consumers: Characteristics, perceptions and satisfaction
}

Received (in revised form): 20th September, 2004

\section{Sylvia M. Chan-Olmsted}

is Associate Professor in Telecommunication at the University of Florida. She received her PhD from Michigan State University with an emphasis in media economics and marketing. She teaches classes in audience analysis, telecommunications management, media strategy and competition, and brand management. Her professional experience includes media planning at agencies and research project management at market research firms.

\section{Jack C. C. Li}

is Assistant Professor in the Department of Communication \& Graduate Institute of Telecommunications at the National Chung Cheng University, Taiwan. He received his PhD from the University of Florida. He is interested in the new media industry, especially in media management and audience analysis.

\section{Jaemin Jung}

is Assistant Professor, Department of Mass Communication, Seoul Women's University. He received his PhD from the University of Florida. His research includes audience analysis, business strategy and performance of media firms and globalisation issues in the media industry.

Jaemin Jung

Dept. of Mass Communication, Seoul Women's University, 126 Gongreung-Dong, Nowon-Gu, Seoul, South Korea.

Tel: +82 29705881 ; Fax: +82 2970 5964; e-mail: jaeminj@hotmail.com

Abstract This study investigates the nature of cable modem consumers by profiling the characteristics, perceptions and satisfaction of the early cable modem adopters. The findings generally support the literature of innovations adoption in regard to the socioeconomic, media use and media ownership characteristics of early adopters. The results also reinforce the personality traits of innovativeness and information seeking for early technology users. There also seems to be some carryover effect from cable television to cable modem satisfaction.

\section{INTRODUCTION}

Digital convergence is becoming a reality as the distinctions between computers and television start to blur. Among the factors driving the emergence of the all-digital television households, the most important is perhaps the growth of cable modem and digital subscriber line (DSL) broadband connections. These so-called broadband services make possible fast access to web pages, interactive video programming, realistic computer games and rentable downloaded software packages.
While cable modem has been the frontrunner of broadband connections in recent years, DSL was quickly gaining ground by early 2001, growing three times faster than its cable counterpart. ${ }^{1}$ As the demand for broadband services outpaced the growth of internet use despite a slowing economy in late 2001, industry analysts predict a bright outlook for both high-speed access services. ${ }^{2-5}$ In fact, after a growth rate of 62 per cent in 2001, the DSL and cable modem broadband services now account for more than 15 per cent of the overall online 
market. ${ }^{6}$ The Yankee Group estimated that by 2005 , there would be more than 31 million broadband subscribers with cable leading DSL in market shares. The competition between DSL and cable modem in the USA has been somewhat of a roller-coaster ride with cable modem leading DSL almost three to one during the spring of 2000 (65 per cent to 24 per cent). Cable's market share, however, declined to 51 per cent a year after as DSL climbed to 39 per cent. By the end of 2001, cable again garnered a 62 per cent share as DSL slid to 37 per cent. ${ }^{7,8}$

Cable modem consumers were also found to be generally more satisfied than DSL consumers; however, there are differences among the customers of individual service providers. As DSL deployment forges ahead, broadband industry observers expect DSL to remain a strong contender; citing that DSL's improving operational efficiencies, marketing and service area coverage are gradually winning the provisioning speed and service satisfaction offered by cable. ${ }^{9}$

With a 15 per cent household penetration, the broadband connection market is entering the growth stage of its product life cycle. ${ }^{10}$ Accordingly, the race between cable and DSL is likely to be steered by their marketing and differentiation efforts. The reported differences in customer satisfaction for individual cable modem service providers further illustrate the necessity of a changing emphasis from building 'systems' to 'customers'. To add to the body of knowledge in broadband consumers, this study will investigate the nature of cable modem consumers by profiling the characteristics, perceptions and satisfaction of the early cable modem adopters.

\section{LITERATURE REVIEW}

The adoption of new media technologies and services has been an important issue for both media practitioners and academics. Prior studies have focused on the demographic characteristics and media use behaviours as critical predictors of rate of adoption. ${ }^{11-20}$ Whereas the former is predicated on the belief of innovation-seeking traits of individuals, and early adopters in particular, the latter is assumed to reflect media users' degree of aspiration for media substitutes. Research in this tradition is based primarily on the conceptualisations proposed by Rogers, who suggested that both attributes of the innovation and innovativeness of the adopters are apt to determine the likelihood and rate of adoption. ${ }^{21}$ Another approach to new media adoption is rooted in the concept of users' utilities and gratifications. ${ }^{2-30}$ Research in this tradition emphasises the usefulness, performance and perceived benefits of as well as satisfaction with the new technology. Relevant adopter studies that examined the specific factors discussed in this study are presented next.

\section{Demographic composition}

Earlier studies suggested that adopters of new media technology tend to have a higher socioeconomic status such as higher education and income levels. ${ }^{31-33}$ Lin also pointed out that financial resource is an important factor in determining individual adoption of an innovation. ${ }^{34}$ The findings generally support Rogers' proposition that early adoption of technological innovations is a function of increasing education and socioeconomic status. ${ }^{35}$ Rogers hypothesised that age does not have significant impact on the rate of adoption. ${ }^{36}$ Numerous studies, however, have found that adopters of innovations tend to be younger. ${ }^{37-42}$ Specifically, it 
was found that age is inversely related to internet access, while education is positively related to internet adoption. ${ }^{43}$

\section{Media use}

Research on adoption of innovations often examines the relationship of adoption rate to other media use. Findings are at best inconclusive. ${ }^{44}$ While some earlier studies found that cable television subscribers spend more time with other media, ${ }^{45,46}$ other adoption literature concluded that media use is irrelevant to adoption of innovations such as videotext and internet. ${ }^{47,48}$ The irrelevance of media use behaviour contradicts Rogers's hypothesis that early adopters often have greater exposure to mass media communications channels and are likely to seek information about innovation more actively. ${ }^{49}$ A possible reason for this discrepancy might be that prior studies have focused mainly on the 'intensity' rather than the 'breadth' of media exposure. ${ }^{50}$

To the extent that a new media technology such as cable television and high-definition television are functionally similar to traditional television and serve similar needs, ${ }^{51}$ the concept of 'media use intensity' for a particular technology cluster might also be an adoption predictor. For example, as the primary function of a cable modem service is to provide high-speed 'cable' connection to the 'Internet' via 'computer', the frequency, amount of time and tenure in using cable service, computer and the internet would appear to be good predictors for cable modem subscription.

As for the specific characteristics of internet users, studies have shown that online users are more likely to be heavier newspaper readers or radio listeners and light television viewers. ${ }^{52,53}$ Industry analysts also found that those who have had online access longer spend a relatively larger amount of time online. ${ }^{54}$ There are also studies suggesting that heavy online users (people who report being on the web three or more hours a day), surprisingly, are very involved with other media. In fact, heavy internet users spend more hours watching television than the light internet users. ${ }^{55}$

\section{Media/Communication technology ownership}

Numerous studies on adoption of innovations have indicated a positive relationship between new media adoption and ownership of other media innovations. ${ }^{56-60}$ For example, Rogers conceptualised the interdependent relationship as a 'technology cluster', which "consists of one or more distinguishable elements of technology that are perceived as being closely interrelated'. ${ }^{61}$ The notion of 'functional similarity' further suggested that media ownership is an important factor in triggering the adoption of subsequent functionally similar new media technologies. ${ }^{62,63}$

Whereas the above perspective stresses the functional similarity of media technologies in a cluster, there is an alternative interpretation from the perspective of socioeconomic status. In his study on HDTV adoption, Dupagne pointed out that people of higher socioeconomic status are more likely to own consumer electronic items. ${ }^{64}$ Lin also suggested that people with better financial resources are more likely to judge new media products on the basis of the intrinsic value rather than the actual monetary cost. ${ }^{65}$

The growth of online services may actually be good news for the multichannel media industries as one report concluded that households equipped with PCs and online 
subscriptions are more likely to spend money on cable television and related services. Data gathered in the Yankee Group's Technologically Advanced Family (TAF) survey of over 2,000 US homes found that subscription rates for basic cable as well as enhanced services like premium channels, Pay-Per-View and Direct Broadcast Satellite (DBS) ran significantly higher among PC and online homes than for the overall public. ${ }^{66}$

\section{Innovativeness traits}

Some studies have started to examine the factor of individual innovativeness personality in relation to the rate of adoption. ${ }^{67,68}$ According to Rogers, innovativeness is 'the degree to which an individual or other unit of adoption is relatively earlier in adopting new ideas than other members of a system'. ${ }^{69}$

Rogers suggested that innovators are often venturesome in nature and obsessive with innovations. Moreover, they are more capable of confronting uncertainty and willing to take risks. As for early adopters, the second group to adopt a technological innovation, Rogers characterised them as respected opinion leaders who play a critical role in diffusing innovation. ${ }^{70}$ In regard to the adoption of internet, Atkin et al. suggested that a consumer's interest in trying new technologies and staying up-to-date with them, along with home computer ownership, are related to internet access. ${ }^{71}$ Lin further concluded that innovativeness need was a significant predictor for the adoption of personal computers. $^{72}$

\section{Needs, reasons for adoption and satisfaction}

A number of earlier studies also attempted to examine the adoption of new media technologies from the perspective of users' utilities. Some focused on the extent to which the improved features of the new media technology, such as cable television and high-definition television, can better satisfy the user's needs than the traditional ones. ${ }^{73-77}$ Some stressed the uses and gratifications aspects of the new media technology ${ }^{78-80}$ The general conceptual framework in this approach is that those who perceive a higher level of utilities or satisfaction from the new technology and those who hold favourable attitudes towards the technology are more likely to become earlier adopters.

In regard to termination of cable modem service, Jacobs concluded that continued adoption is dependent on how well the service actually met a subscriber's expectation of the service. ${ }^{81}$ LaRose and Atkin also suggested that consumer satisfaction with current cable programming was not only a good predictor for continued adoption of cable television but also for other technology devices. ${ }^{82}$

As for the reasons that an internet user subscribes to a cable modem broadband connection service, it might be useful to examine the current popular activities among online users as the factors that enable such activities to be carried out more effectively and efficiently will probably be regarded as more important to these users. An industry report on internet activities found that over half of the online Americans now say they go online to make purchases. According to the same study, the top five most popular online activities are 'doing research', 'communicating with friends/family', 'getting information about products', 'getting news/health information' and 'making purchases'. 'Information gathering' is especially important for more experienced online users. ${ }^{83}$ Another study on technology adoption based on a 
survey of 2,000 persons also cited that 'make purchase for work', 'download software' and 'e-mail' to be the important internet uses for early adopters. In regard to specific reasons why early adopters are interested in high-speed access, a Forrester Research study found that 'constant connection', 'faster connection', 'better entertainment and games' and 'increased productivity' to be the top four reasons cited by online consumers. ${ }^{84}$

\section{Current study}

The purpose of this study is to investigate the nature of the consumers of one particular technological innovation, cable modem. Note that this paper does not intend to identify the predictors of the cable modem adoption but to better understand the existing consumers and the factors that might influence their subscription, satisfaction and decisions to terminate cable modem service. Where appropriate, the profile (eg demographics and media use/ownership) of the cable modem consumers is compared to that of the general online users to assess the differences between cable modem and general online consumers. Because the current penetration rate of cable modem is less than 10 per cent, both nationally and for the local system at focus, based on Rogers' adopter categorisation, the subscribers in this study are considered to be either innovators or early adopters in the process of cable modem adoption. ${ }^{85}$

Innovators are the technology enthusiasts who appreciate the technology for its own sake and are the first people adopting any new technology. For example, they are the ones who buy HDTVs, DVD players and digital cameras when they each cost considerable money. Early adopters, the next group in the technology adoption life cycle, are the visionaries who adopt new technology following the innovators. These groups represent an opportunity in a product's life cycle to generate a burst of revenue and gain exceptional visibility. Without this boost, many high-tech products cannot make it to the market, unable to gain the visibility they need within their window of opportunity, or unable to sustain their financial obligations while waiting for their marketplace to develop more slowly. In fact, there is a real chasm between the first two groups (innovators and early adopters) and the next group, the early majority. To achieve a profitable market, this discontinuity or chasm ought to be overcome by lowering the barrier to the early majority. ${ }^{86,87}$ Thus, it is necessary to better understand the characteristics, perceptions and satisfaction of the innovators and the early adopters in the technology adoption cycle.

Drawing from the literature reviewed, the cable modem consumers are expected to display certain demographic and attitudinal characteristics. Thus, the first two research questions explored the socioeconomic, media and innovativeness profile of cable modem consumers.

RQ1: What are the demographic, media use and media ownership characteristics of cable modem consumers? Are the earlier adopters different from the later adopters in regard to these characteristics?

RQ2: Do cable modem consumers possess traits of innovativeness? Are the earlier adopters different from the later adopters in regard to these characteristics?

Consistent with prior studies, cable modem consumers are expected to be relatively young; have high education and income; use multiple traditional 
media, especially print media; own many communication technology products; and be experienced, heavy users of the internet, PC and cable services, which are technologically similar to cable modem. It is anticipated that a cable modem consumer would possess innovative personal traits, have positive attitudes toward technology, be an active information seeker and perceive himself/herself to be knowledgeable with issues relevant to broadband services. The earlier adopters are expected to have even higher socioeconomic status, be more innovative and exhibit more evident media use/ownership characteristics than those of the later adopters.

The next research question explored the factors contributing to the adoption and possible termination of cable modem service.

RQ3: What factors are related to the adoption and termination of cable modem service? Are the factors for earlier adopters different from those of the later adopters?

Based on the relevant studies reviewed, 'total time' and 'frequency' spent online and his/her tenure (ie length of time) in internet and PC use, along with the desire for fast access to the internet and information, are expected to contribute to his/her decision to adopt cable modem. Because of the expected higher socioeconomic status and the personality traits of the innovator/early adopter as depicted in earlier studies, ${ }^{88}$ pricing or peer influence are not anticipated to be main factors in a consumer's decision to subscribe to cable modem. In regard to termination, the factors of unrealised expectation, failure of the current service in executing the most popular online activities (eg online purchase, information gathering, download material, etc) as efficiently as perceived, and negative perceptions toward cable television, cable modem or overall cable services to contribute to the likelihood of discontinuing cable modem service. The identified factors are also expected to be more important for earlier adopters than the later adopters. Lastly, consumers' degree of satisfaction towards current cable modem service and perception of other relevant potential services that might be provided by the cable system operator are investigated.

RQ4: How satisfied are the cable modem consumers with their cable modem service? What factors are related to the degree of satisfaction? Does the degree of satisfaction differ between earlier and later adopters?

RQ5: What are cable modem consumers' attitudes towards telecommunications product bundling and potential cable telephone services? What factors are related to cable modem consumers' attitudes towards telecommunications product bundling and potential cable telephone services?

These consumers are expected to exhibit a lower level of satisfaction for cable modem as compared to what they would acknowledge for cable television services for the following reasons: 1) cable modem is a relatively new service that focuses on the delivery rather than the provision of content (ie a relatively new concept for a cable system operator), so that the system operator is still adapting to the new business mandate; and 2) the consumers of cable modem are much more experienced with cable television services and thus may have more 
realistic expectation for this type of service. The earlier adopters (eg innovators), who have had more experience using cable modem service, are anticipated to exhibit more realistic expectation and thus a higher level of satisfaction. It is likely that cable modem users' level of satisfaction towards cable services, especially cable modem, would influence their attitudes towards other potential services such as cable telephone services.

\section{METHOD}

A web-based online survey was administered between mid-October and early November 2000 to the cable modem consumers in a mid-size town in southeast USA. The high-speed internet access product, at the time of the survey, was available in either one-way or two-way, and in three pricing tiers depending on download and upload speeds (and total hours used in case of the one-way system). A research report of three focus groups conducted by the cable modem service provider (ie the cable system operator) was made available to the authors for generating survey questions, which were pre-tested on three current cable modem consumers (results not included in this study).

An introductory e-mail explaining the nature of the survey and containing the URL link to the online questionnaire was sent to all 707 current cable modem subscribers, using the e-mail addresses provided by the system operator. Reminder e-mail messages were sent to all non-respondents one week after the initial contact. Approximately 621 e-mail messages were delivered successfully. Of those contacted, 220 respondents completed the online survey, with a response rate of 35.4 per cent.

\section{Operational measures}

\section{Demographic composition and media use patterns}

The demographic factors of age, education, gender, marital status and household income were investigated. There was a relatively higher percentage of young and educated users which may be explained by the community being a university town in addition to the general finding that it is more likely for younger, educated online users to adopt new technologies. ${ }^{89}$ The respondents were asked to estimate the number of hours in an average day that they spent using television/radio and weekly frequencies in reading newspapers/magazines, cinema attendance, video rental and DVD rental. To assess the respondents' media use patterns for the related technology cluster, they were asked how long they had been using cable modem, the internet, cable television and PC. In regard to the internet, the respondents also indicated how frequently they $\log$ on (frequency) and how much time they spent online per day (intensity).

\section{Media/Communication technology ownership}

To measure the degree of media/communication technology ownership, respondents were asked whether they own or subscribe to the following media/communication technology products: PC, DVD player, cell phone, video game player, Personal Digital Assistant (PDA) hand-held computers, large-screen television, home theatre system, premium cable television service, DBS, DSL, ISP and a second phone line specifically used for dial-up connections. Media ownership variables were coded as dummies, with one as 'yes' and zero as 'no.' 
Information competency

To measure the cable modem subscribers' self-assessed knowledge towards broadband/new media services and their information-seeking tendency, respondents were asked how strongly they agree with four statements using a five-point Likert-like scale in which response categories range from one as 'strongly disagree' to five as 'strongly agree.90 To examine whether the four statements would indicate different dimensions of information-seeking tendency, the responses were subjected to factor analysis and reliability tests. The factor analysis procedure successfully combined the statements into an 'information competency' factor with a Cronbach's alpha of 0.85 .

\section{Perceptions and satisfaction towards services}

The respondents' attitudes towards bundling services and possible cable telephony service were investigated to assess the potential of such marketing practices as many have anticipated the growth of telephone-cable integrated services. ${ }^{91}$ The three bundling statements were collapsed into one factor with a Cronbach's alpha of 0.56 .

The survey also measured the respondents' level of satisfaction, using the same five-point scale, towards the current system operator's overall cable services; cable modem service; and customer service, installation, technical support, pricing, reliability, value and expectation fulfilled in regard to cable modem. Factor analysis yielded two factors, that of 'general satisfaction' (eg reliability, expectation and overall service) and that of 'specific satisfaction' (eg modem installation, modem customer service, and modem technical support). ${ }^{92}$

To measure the intent to discontinue the current cable modem service, the respondents were asked to indicate how likely they were to cancel the cable modem service in the near future using a five-point Likert-like scale with responses range from one as very unlikely to five as very likely.

\section{Innovativeness traits}

Utilising the instrument for measuring innovativeness established by Lin, nine statements were used to assess the innovativeness traits of the respondents. The same five-point scale was used. The responses were factor analysed to see whether the statements would result in different dimensions of innovativeness. The factor analysis produced only one unique factor, 'innovativeness traits', with a Cronbach's alpha of $0.92 .{ }^{93}$

Factors influencing cable modem adoption and termination

In regard to the reasons for subscribing to the cable modem service, the respondents were asked to rank their agreement, using the same five-point scale, on a series of 18 reasons for subscribing to cable modem (see Table 2 ). The respondents were also asked to rank the importance of the following five general types of utilities, with one being the most important and five the least, as their reasons for going online: communication, information, online purchases, socialisation and entertainment. As for motivations behind the possible disconnection of cable modem, the respondents were asked to self-identify the reasons that might contribute to such decisions.

To explore the influence of the aforementioned variables/factors on cable modem subscription, satisfaction and termination, where appropriate, multivariate statistics such as regression analysis were performed using the independent variables that were 
Table 1: Characteristics of cable modem consumers

\begin{tabular}{ll}
\hline Media experience & Mean \\
\hline PC tenure & 10.7 years \\
Online tenure & 6 years \\
Cable television tenure & 11.8 years \\
Cable modem tenure & 6 months \\
Media/Communication technology ownership & $\%$ Owned the device \\
Cell phone & 75.9 \\
Video game player & 59.5 \\
DVD player & 57 \\
Large-screen television & 56.4 \\
Home theatre system & 40 \\
PDA & 23.6 \\
DSL (previous ownership) & 7.3 \\
DBS (previous ownership) & 10 \\
& \\
Media use & Hours or frequency \\
Go online & 3.8 hours per day \\
Watch television & 2.7 hours per day \\
Listen to radio & 2 hours per day \\
Read newspapers & 4 days per week \\
Read magazines & 3 magazines per week \\
See theatrical movies & 1.8 movies per month \\
Rent DVDs/Videotapes & $1.3 / 0.6$ per week \\
\hline
\end{tabular}

significantly related to the selected dependent variable. In such cases, stepwise procedures were applied in which independent variables were entered in order of the significance of Pearson correlation coefficients.

\section{RESULTS}

\section{Characteristics of the cable modem consumers}

Table 1 shows that the cable modem consumers appeared to be experienced PC and online users. Due to the relative newness of the cable modem service at the time of the survey, while some respondents have been using cable modems for up to three years, the average consumers have been subscribing to the broadband access service for approximately half a year. Comparing the communication technology ownership of the cable modem consumers to that of average online households as reported by Nielsen Media during the comparable time period, ${ }^{94}$ cable modem users were found to be more likely to own DVD players (57 per cent versus 9.5 per cent), video game players (59.5 per cent versus 33.1 per cent), home theatre systems ( 40 per cent versus 25.5 per cent), cell phones (75.9 per cent versus 65 per cent), large-screen televisions (56.4 per cent versus 48.4 per cent) and, just slightly, PDAs (23.6 per cent versus 22.5 per cent). As for media use pattern, cable modem consumers spent almost twice as much time per day online as average online users (3.8 versus 2 hours). Interestingly, the same consumers rented twice as many DVDs as videotapes weekly. The cable modem users also consumed less television and radio with an average of 2.7 hours of television viewing and two hours of radio listening a day in comparison to 4.2 and 3.3 hours per day for a typical adult in the USA. $^{95,96}$ In sum, cable modem consumers seem to be very experienced with innovations in the similar technology cluster and more inclined to 
Table 2: Reasons for cable modem subscription and correlations with cable modem tenure, satisfaction and termination likelihood

\begin{tabular}{|c|c|c|c|c|c|}
\hline Reasons for cable modem subscription & MEAN & $\begin{array}{l}\text { Standard } \\
\text { deviation }\end{array}$ & $\begin{array}{l}\text { Modem } \\
\text { tenure }\end{array}$ & Satisfaction & Termination \\
\hline It gives me faster internet access & 4.54 & 0.78 & 0.09 & $0.15^{\star}$ & $-0.15^{\star}$ \\
\hline I want to download research material faster\# & 4.25 & 0.89 & -0.05 & -0.03 & 0.01 \\
\hline I want to download music or video faster & 4.09 & 1.19 & $-0.15^{\star}$ & 0.11 & -0.06 \\
\hline It enhances my productivity & 4.02 & 0.90 & 0.07 & 0.14 & $-0.22^{\star \star}$ \\
\hline I want to keep up with new technology & 3.86 & 0.87 & 0.01 & $0.16^{*}$ & $-0.22^{\star \star}$ \\
\hline $\begin{array}{l}\text { I want to be able to make telephone calls via cable } \\
\text { when available }\end{array}$ & 3.47 & 1.16 & -0.01 & $0.19^{\star \star}$ & $-0.17^{*}$ \\
\hline I like the 'always on' feature & 3.38 & 1.48 & $-0.15^{\star}$ & $0.36^{\star *}$ & $-0.28^{\star \star}$ \\
\hline It offers good value & 3.22 & 1.01 & -0.01 & $0.38^{\star *}$ & $-0.32^{\star *}$ \\
\hline My cable company offers good services & 3.08 & 1.09 & -0.02 & $0.66^{\star *}$ & $-0.53^{\star \star}$ \\
\hline It doesn't tie up my phone line & 3.05 & 1.71 & $-0.19^{\star \star}$ & $0.45^{\star \star}$ & $-0.28^{\star *}$ \\
\hline
\end{tabular}

\#Factor analysis eliminated these three statements, which loaded on more than one factor.

${ }^{*}$ Correlation was significant at 0.05 level (2-tailed). ${ }^{\star *}$ Correlation was significant at 0.01 level (2-tailed).

own multiple communication

technological devices than average online users. They also are likely to be regular consumers of a variety of media, new video device enthusiasts, more avid online users, but less interested in traditional broadcast media than the typical media consumers.

\section{Characteristics by consumer tenure}

To assess the relative differences in demographic, media use and media ownership profiles between the earlier and later adopters, multiple regression was performed using the independent characteristic variables that were significantly related to cable modem tenure at the 0.01 level. ${ }^{97}$ Overall, the equation accounted for 24 per cent of the observed variance. The independent variables of age $(\beta=0.34)$, magazine use $(\beta=0.15)$, and PC tenure $(\beta=0.14)$ were found to be significant. It seems that the earliest adopters tend to be more mature in age, more likely to spend time reading magazines and seasoned PC users. Interestingly, though earlier modem adopters were more likely to have been online longer (ie online tenure), they did not $\log$ on more frequently or spend more time online than the later adopters. $^{98}$

\section{Innovativeness traits}

The cable modem consumers recorded mean scores ranging between 4.1 and 4.7 for the nine innovativeness statements. These consumers seem to possess innovativeness traits that are present in studies of other technological innovations. There, however, appears to be no statistically significant relationship between cable modem tenure and such innovativeness traits (for all individual measures as well as the resultant innovativeness factor). ${ }^{99}$

\section{Factors related to adoption of cable modem service}

Respondents ranked reasons such as 'fast Internet access,' 'use Internet often', 
Table 3: Factor analyses of cable modem adoption reasons

\begin{tabular}{|c|c|c|c|c|c|}
\hline Statements of subscription reasons & $\begin{array}{l}\text { System- } \\
\text { oriented } \\
\text { utilities }\end{array}$ & $\begin{array}{l}\text { Innovativeness/ } \\
\text { productivity }\end{array}$ & $\begin{array}{l}\text { Peer } \\
\text { influence }\end{array}$ & $\begin{array}{l}\text { Value and } \\
\text { service }\end{array}$ & $\begin{array}{c}\text { Content- } \\
\text { oriented } \\
\text { utilities }\end{array}$ \\
\hline It doesn't tie up my phone line & 0.85 & & & & \\
\hline Like the 'always on' feature & 0.83 & & & & \\
\hline I want to upload files faster & 0.73 & & & & \\
\hline Gives me faster internet access & & -0.79 & & & \\
\hline Enhances my productivity & & -0.74 & & & \\
\hline Want to keep up with new technology & & -0.74 & & & \\
\hline Use the internet all the time. & & -0.71 & & & \\
\hline My friends/family also subscribe to it & & & 0.93 & & \\
\hline My friends/family recommended it & & & 0.92 & & \\
\hline It is affordable & & & & -0.90 & \\
\hline It offers good value & & & & -0.74 & \\
\hline My cable company offers good services & & & & -0.49 & \\
\hline Want to watch video on my computer & & & & & 0.88 \\
\hline Want to download music or video faster & & & & & 0.83 \\
\hline $\begin{array}{l}\text { Want to make telephone calls via } \\
\text { cable when it is available }\end{array}$ & & & & -0.40 & 0.50 \\
\hline Eigen value & 4.28 & $\begin{array}{c}1.97 \\
13.15 \%\end{array}$ & $\begin{array}{l}1.47 \\
9.80 \%\end{array}$ & $\begin{array}{l}1.42 \\
9.50 \%\end{array}$ & 1.28 \\
\hline
\end{tabular}

'enhance my productivity' and 'fast download' relatively high in their decision to adopt cable modem (see Table 2). On the other hand, they did not see peers' opinions, image and other trial-related motivations to relate to their decision to subscribe.

To assess the underlying reasons for cable modem adoption more succinctly, factor analysis was performed which yielded five adoption reason factors (see Table 3). They were 'system-oriented utilities' (Cronbach's alpha $=0.76$ ), which combined three statements that measured the respondents' desire to use the delivery/access system efficiently; 'innovativeness/productivity' (Cronbach's alpha $=0.75)$, which reflected the modem consumers' innovativeness traits and their needs to enhance the utility of those traits; 'peer influence' (Cronbach's alpha $=0.86)$, which combined statements that assessed the influence of the consumers' peers; 'value and service' (Cronbach's alpha $=0.74$ ), which pointed to the respondents' positive perceptions toward the value and service provided; and 'content-oriented utilities'
(Cronbach's alpha $=0.72)$, which gauged the consumers' desire to receive content such as video and music and usage for secondary services such as making phone calls. Among all, 'system-oriented utilities' seemed to be the most pervasive reasons for cable modem consumption.

\section{Reasons for adoption and cable modem tenure}

Correlation analysis between the five reason factors and modem tenure revealed that the earlier adopters were less likely to be influenced by peers $(r=-0.22, p<0.01) .{ }^{100}$ Further correlation analysis of modem tenure and 'individual' adoption reasons also revealed the earlier adopters' disinterest in music/video download, self-image fulfilment and the always-on online access feature through cable modem use (see also Table 2). Since cable modem users primarily use this service to go online, the types of utilities (ie communication, information, online purchases, socialisation and entertainment) sought when a modem 
consumer goes online were also reviewed. It was found that, consistent with previous studies, earlier adopters more frequently cited 'information' $(r=-0.16, p=0.05)$ as the most important and socialisation $(r=0.18$, $p=0.05)$ as the least important reason to go online.

\section{Reasons for adoption and consumers' characteristics}

The relationship between a modem consumer's profile and his/her reasons for adoption were further examined.

Correlation analysis indicated that the consumers who had been online longer (ie online tenure) were more likely to consider 'innovativeness/productivity' as an important reason factor for modem subscription $(r=0.19, p<0.01)$. PC veterans were less likely to cite 'peer influence' as a reason for modem adoption $(r=-0.16, p=0.02)$. Consumers who went online more frequently and spent more time there were more likely to cite 'innovativeness/productivity' as an important factor of adoption (frequency $r=0.15, p=0.03$; intensity $r=0.23$, $p<0.01)$. Also, consumers who used the internet more frequently were more likely to regard 'system-oriented' and 'content-oriented' utilities as reasons of subscription $(r=0.17, p=0.01$; $r=0.15, p=0.03)$. Subscribers of premium cable channels were more inclined to cite 'system-oriented utilities' as reasons of modem adoption $(r=0.16$, $p=0.02)$. The factor of 'value/service' was not significantly related to any of these variables.

\section{Reasons contributed to likelihood of service termination}

Among the reasons cited for possible termination of cable modem service, internal technical/service problems and inadequate perceived value of the modem service seem to matter more in the decision to terminate than competition posed by the DSL alternative. While many subscribers named connection problems (35.1 per cent), unreliable service (35.1 per cent), technical problems (32.7 per cent), unsatisfactory customer service (30.3 per cent) and high price (44.7 per cent) as the factors contributing to the possibility of service termination, only 25 per cent of them indicated switching to DSL as a reason for possible termination.

To assess the relative influence of information competency, satisfaction and reason factors in such termination decisions, multiple regression was performed using the variables/factors that were significantly related to the termination variable at the 0.01 level. ${ }^{101}$ Overall, the equation accounted for 43 per cent of the observed variance. The independent variables/factors of 'general satisfaction' $(\beta=-0.65)$ and 'innovativeness and productivity' reason factor $(\beta=-0.12)$ were found to be significant. It seems that it would be less likely for a consumer to terminate his/her modem service if he/she is satisfied with the 'overall cable services' provided by his/her system operator and he/she has adopted cable modem to enhance his/her productivity and/or innovativeness traits.

\section{Satisfaction with cable modem service}

In comparison to the level of satisfaction for cable television service $(M=3.40)$, cable modem $(M=2.87)$ earned a much lower mean score (see Table 4). Many respondents stated that the cable modem service was not what they had expected $(M=2.96)$ and the service has not been very reliable $(M=2.54)$. 
Table 4: Perceptions/satisfaction of cable services and correlations with cable modem tenure, satisfaction, and termination likelihood

\begin{tabular}{|c|c|c|c|c|c|}
\hline Perception/satisfaction of service & MEAN & $\begin{array}{l}\text { Standard } \\
\text { deviation }\end{array}$ & $\begin{array}{l}\text { Modem } \\
\text { tenure }\end{array}$ & Satisfaction & Termination \\
\hline $\begin{array}{l}\text { I am satisfied with the overall services } \\
\text { provided by my cable company }\end{array}$ & 3.11 & 1.11 & -0.01 & $0.75^{\star \star}$ & $-0.55^{\star *}$ \\
\hline I am satisfied with my cable TV service & 3.40 & 1.01 & -0.06 & $0.33^{\star *}$ & $-0.21^{\star \star}$ \\
\hline I am satisfied with my cable modem service & 2.87 & 1.28 & -0.05 & - & $-0.65^{\star \star}$ \\
\hline $\begin{array}{l}\text { I am satisfied with my cable company's } \\
\text { customer service for cable modem }\end{array}$ & 3.11 & 1.23 & -0.01 & $0.60^{\star *}$ & $-0.41^{\star \star}$ \\
\hline $\begin{array}{l}\text { I am satisfied with my cable modem's } \\
\text { installation }\end{array}$ & 3.70 & 1.10 & 0.12 & $0.26^{\star \star}$ & $-0.17^{\star \star}$ \\
\hline $\begin{array}{l}\text { My cable modem service is just like what I } \\
\text { have expected }\end{array}$ & 2.96 & 1.29 & 0.08 & $0.78^{\star *}$ & $-0.57^{\star *}$ \\
\hline $\begin{array}{l}\text { My cable company offers good technical } \\
\text { support for cable modem }\end{array}$ & 3.02 & 1.17 & 0.03 & $0.62^{\star *}$ & $-0.42^{\star \star}$ \\
\hline The price for my cable modem service is fair & 2.77 & 1.12 & 0.12 & $0.44^{\star \star}$ & $-0.39^{\star \star}$ \\
\hline My cable modem service has been reliable & 2.54 & 1.38 & -0.03 & $0.80^{\star \star}$ & $-0.57^{\star \star}$ \\
\hline $\begin{array}{l}\text { Benefits of cable modem are worth the } \\
\text { price I pay }\end{array}$ & 3.08 & 1.14 & 0.06 & $0.64^{* *}$ & $-0.49^{\star \star}$ \\
\hline
\end{tabular}

${ }^{*}$ Correlation is significant at 0.05 level (2-tailed).

${ }^{\star *}$ Correlation is significant at 0.01 level (2-tailed).

The degree of cable modem satisfaction seems to be negatively related to demographic characteristics such as age $(\mathrm{r}=-0.19)$, education $(\mathrm{r}=-0.23)$, and income $(\mathrm{r}=-0.19),{ }^{102}$ but positively related to eight specific perception and satisfaction variables (see Table 4). Multiple regression was performed to assess the relative importance of these perception/satisfaction variables in determining the degree of cable modem satisfaction. Overall, the equation accounted for 76 per cent of the observed variance. 'Cable modem reliability' $(\beta=0.44)$, 'fulfilled expectations' $(\beta=0.35)$, 'cable modem customer service' $(\beta=0.19)$, and 'cable television satisfaction' $(\beta=0.08)$ were found to be significant. The expected performance and customer support to realise that performance seem to be more essential than the perceived value of the service in influencing the level of cable modem satisfaction. Interestingly, a certain degree of carryover effects from cable television satisfaction to cable modem satisfaction were found.

To evaluate the relative contribution of subscription reasons in affecting the degree of cable modem satisfaction, multiple regression was performed using the four reason factors that were significantly related to cable modem satisfaction. ${ }^{103}$ Overall, the equation accounted for 35 per cent of the observed variance. 'Value and service' $(\beta=0.47)$ and 'system-oriented utilities' $(\beta=0.22)$ were found to be significant. It seems that a cable modem consumer would be more likely to be satisfied when he/she subscribed to cable modem because of a positive perception towards its value and services and in search of system-oriented utilities.

A person's feeling towards bundling, innovativeness traits and cable modem tenure did not seem to relate to his/her degree of satisfaction towards cable modem. Interestingly, a cable modem consumer who subscribed to DSL before was more likely to be more satisfied with his/her cable modem service $(r=0.19$, $p=0.01)$.

\section{Attitude towards potential services}

The cable modem consumers were interested in bundled services, particularly 
package discounts for combining services such as cable television, cable modem and telephone services $(M=4.34)$. These consumers, while having a somewhat positive attitude towards the integrated, single billing possibility $(M=4.07)$, were not particularly interested in subscribing to cable telephone service when it was available $(M=3.46)$. None of these variables were related to cable modem tenure, termination likelihood or cable modem satisfaction.

Correlation analyses of individual potential bundling/service statements reveal some interesting findings. Cable modem consumers who have been online longer or were active information seekers were more interested in the integrated, single billing possibility $(r=0.18, p<0.01 ; r=0.18, p<0.01)$. Consumers who were more innovative, as measured by the factor of innovative personality traits, were more likely to have positive attitudes towards single billing $(r=0.38, p<0.01)$ or discount of bundled telecommunications services $(r=0.22, p<0.01)$. Based on this result, the effectiveness of the cross-selling tool, frequently mentioned in the field of the customer relationship management (CRM), can be realised. Clamouring for ways to snare new customers and squeeze more revenues from the ones the companies have, the more strategic approach for choosing the right package in the telecommunication industry is needed.

In terms of the relationship between such potential services and reasons for modem subscription, the modem users who regarded 'value and services' as important adoption reasons were more positive towards the cable telephone possibility $(r=0.22, p<0.01)$, while the 'content-oriented' consumers were more likely to be interested in single billing $(r=0.16, p=0.02)$ or cable telephone service $(r=0.18, p<0.01)$.

\section{DISCUSSION AND CONCLUSION}

Findings for this study generally support the literature of innovations adoption in regard to the socioeconomic, media use and media ownership characteristics of early adopters. The results also reinforce the personality traits of innovativeness and information seeking for early technology users. In partial departure from the findings of previous work, it was found that a distinction between 'technology' cluster and 'functional' cluster is sometimes necessary when examining the introduction of a technological innovation, such as cable modem, that involves multiple technologies (eg cable television, PC and internet) designed for different primary functions. In such cases, the related existing technology that provides a different utility would probably offer less relevance, and thus less predictive power, for anticipating the characteristics of the consumer of the new innovation in the same technology cluster.

Though exploratory in nature, considering the unusually high proportion of young, educated subscribers for this particular cable modem service, it is clear that current cable modem consumers possess many traits of early adopters. Namely, they are often at the higher end of the socioeconomic ladder and are multiple media/communication technology users/owners. As expected, these early adopters are heavier online users, lighter television/radio users and heavier print media users. The socioeconomic characteristics and media patterns continue to hold true on examining further the differences within these consumers. The only exception is the factor of age; it seems that the earliest adopters are more likely to be more mature in age than the later adopters within the groups of innovators and early adopters of cable modem. This discovery 
actually adds another aspect to Atkin et al.s finding of the inverse relationship between age and internet access. ${ }^{104}$ The authors believe that when an innovation to be adopted is considered an 'enhancement' to another technology (eg cable modem enhances internet access) there might be a positive, curvilinear relationship between age and the adoption of such an enhancement technology during the initial stage of adoption. In sum, considering that cable modem is an innovation that improves rather than replaces the performance of internet connection, it is logical that the earliest adopters would be the ones who have the means (ie higher socioeconomic status and accordingly the more advanced age) to adopt it.

These findings in the media use patterns of early cable modem consumers generally support Rogers's notion that early adopters often have greater exposure to communications channels and are active information seekers. ${ }^{105} \mathrm{It}$ was also found that 'PC tenure' tends to be a better predictor of 'early' cable modem adoption compared to cable television service and internet use which are technologically or functionally-related to cable modem. It is interesting that, while the early cable modem adopters spend more time online than average online users, the 'earliest' adopters do not use the internet more frequently or more intensely than the later adopters. They also do not exhibit more evident traits of innovativeness. It seems that a person's socioeconomic status and his/her desire to actively and efficiently acquire information via a wide collection of communications channels (ie a focus on the breadth of media exposure) drive the earliest adoption of cable modem.

An examination of the reasons cited for cable modem subscription further supports Rogers' notion that early adopters are opinion leaders, not followers. ${ }^{106}$ While many internet performance-related reasons were reported as the main motives of adoption, peer influence and image factors were largely regarded as irrelevant. Correlation between cable modem tenure and the adoption reason factors does reveal the increasing importance of peers for later adopters. The findings also suggest that internet veterans who are online frequently and constantly are more inclined to regard innovativeness/productivity reasons as the motivation behind their modem subscription.

As expected, cable modem service generates a lower level of satisfaction than that of cable television service. Nevertheless, there seems to be somewhat of a carry-over effect from cable television to cable modem satisfaction. Also as proposed, the more a cable modem consumer perceived that his/her expectation for the modem service is being fulfilled, the more satisfied he/she becomes. Note that customer service and a reliable performance that fulfils prior expectations actually contribute more to cable modem satisfaction than pricing/value issues. The results in consumer characteristics also suggest that more mature, educated, higher income and active information-seeking consumers are harder to please. Interestingly, those who have tried DSL before seem to have a higher degree of satisfaction, possibly due to a more realistic expectation of high-speed connection services.

While the perceived 'value' for cable modem service may not be a factor contributing to the adoption or satisfaction of cable modem service, it could become an important motivation for service termination, especially when the modem service has not performed satisfactorily in regard to its technical delivery. The fact that an increase in 
overall cable service satisfaction would probably reduce the possibility of cable modem termination again reinforces the carry-over effect of 'technology clusters' in areas of satisfaction as well as termination deterrence.

The cable modem consumers, while somewhat interested in receiving package discounts for bundled services, were not particularly enthusiastic about another potential service in the same technology cluster, that is, cable telephone service. It is interesting that a cable modem consumer's degree of satisfaction with his/her current cable modem service is not related to his/her feeling towards such potential services. Instead, the consumer's embedded innovativeness traits, desire for information, online experience and attitude towards value and service are more likely to influence his/her adoption of such potential services.

As discussed earlier, technological similarity should be treated differently from functional similarity in case of bundled services using integrated technologies. It can be argued that as the convergence of multiple delivery systems draws near, it would be unwise to anticipate the nature of demand and use pattern for a new innovation simply based on the understanding of other services in the similar technology cluster. The authors believe that a uses and gratification approach which analyses the utilities/functions sought by a consumer would provide a more appropriate framework in identifying clusters of similar innovations. Just as cable television user characteristics and use pattern may not be a good predictor for the profile of cable modem consumers/adopters, cable modem user characteristics and use pattern may not be the best indicator for cable telephone consumers/adopters and, from a different perspective, telephone user profile may not necessarily be a good source for anticipating the demand and characteristics of DSL consumers/adopters. Nevertheless, these findings also point to the importance of a carry-over effect of 'technology clusters' in creating a technology comfort zone, which might enhance the level of satisfaction or minimise dissatisfaction for technologically-related services.

The results of this study should be interpreted with caution, especially in regard to the socioeconomic characteristics of cable modem consumers, as the survey respondents were disproportionately younger and educated. While the profiling and correlations based entirely on existing cable modem users may allow different aspects of adoption of innovations to be examined, a further examination and comparison of non-users will be the next necessary step.

\section{References}

1 Pastore, M. (2001a) 'DSL customers shrug off service issues', CyberAtlas, 12th March, http://cyberatlas.internet.com/markets/ broadband/article/0..10099_711001.htm, accessed 19th December, 2001.

2 Beard, M. (2001) 'Broadband grows apace, despite economy', Media Life Magazine, 17th December, http://www.medialifemagazine.com/news2001/ dec01/dec17/1_mon/news3m.htm, accessed 19th December, 2001.

3 Cyberatlas (2001) 'Quest for broadband usually ends at cable', 5th September, http://cyberatlas.internet.com/markets/broadband/ article/0..10099_879101.htm, accessed 19th December, 2001.

4 Greenspan, R. (2002) 'Slow but steady speed subscriptions', Cyberatlas, 25th April, http://cyberatlas.internet.com/markets/broadband/ article/0,,10099_1016281,00.html, accessed 29th April, 2002.

5 Stump, M. (2001) 'Telcos' DSL dilemmas a good sign for cable', BroadbandWeek, 3rd December, http://broadbandweek.com/news/011203_ telecom_dsl.thm, accessed 19th December, 2001.

6 Cyberatlas (2002) 'Broadband the bright spot in access market', 27th February, http://www.cyberatlas.internet.com/markets/ broadband/article/0,,10099_982021,00.html, accessed 29th April, 2002.

7 Cyberatlas (2002) op. cit. 
8 Pastore (2001a) op. cit.

9 Pastore, M. (2001b) 'Europe remains behind in broadband game', CyberAtlas, 12th June, http://cyberatlas.internet.com/markets/ broadband/ article/0.10099_783401.htm, accessed 19th December, 2001.

10 Cyberatlas (2002) op. cit.

11 Atkin, D. J., Jeffres, L. W. and Neuendorf. K. A. (1998) 'Understanding internet adoption as telecommunications behavior', Journal of Broadcasting E Electronic Media, Vol. 42, Fall, pp. 475-490.

12 Dickerson, M. D. and Gentry. J. W. (1983) 'Characteristics of adopters and non-adopters of home computers', Journal of Consumer Research, Vol. 10, September, pp. 225-235.

13 Dupagne, M. (1999) 'Exploring the characteristics of potential high-definition television adopters', Journal of Media Economics, Vol. 12, No. 1, pp. $35-50$.

14 Henke, L. and Donohue, T. (1989) 'Functional displacement of traditional TV viewing by VCR owners', Journal of Advertising Research, Vol. 29, April/May, pp. 18-23.

15 Jeffres, L. W. and Atkin. D. J. (1996) 'Predicting use of technologies for communication and consumer needs', Journal of Broadcasting \& Electronic Media, Vol. 40, summer, pp. 318-330.

16 Krugman, D. (1985) 'Evaluating the audiences of the new media', Journal of Advertising, Vol. 14, May/June, pp. 21-27.

17 Lin, C. A. (1998) 'Exploring personal computer adoption dynamics', Journal of Broadcasting E Electronic Media, Vol. 42, winter, pp. 95-112.

18 Lin, C. A. and Jeffres, L. W. (1998) 'Factors influencing the adoption of multimedia cable technology', Journalism \& Mass Communication Quarterly, Vol. 75, summer, pp. 341-352.

19 Neuendorf, K. A., Atkin, D. J. and Jeffres, L. W. (1998) 'Understanding adopters of audio information innovations', Journal of Broadcasting $\mathcal{E}$ Electronic Media, Vol. 42, winter, pp. 80-93.

20 Reagan, J. (1989) 'New technologies and news use: Adopters vs. nonadopters', Journalism Quarterly, Vol. 68, Summer, pp. 871-875.

21 Rogers (1995) suggested five attributes: (1) relative advantage such as economic profitability, social prestige, or other benefits that the innovation can provide; (2) compatibility of the innovation with existing values, past experience and needs of potential adopters; (3) the degree of complexity perceived by potential adopters; (4) trialability; and (5) observability of the results after adoption of the innovation.

22 Atkin, D. J. (1992) 'A profile of cable subscribership: The role of satisfaction', Telematics $\mathcal{E}$ Informatics, Vol. 9, spring, pp. 53-60.

23 Ducey, R. V., Krugman, D. M. and Eckrich, D. (1983) 'Predicting market segments in the cable industry: The basic and pay subscribers', Journal of Broadcasting, Vol. 27, spring, pp. 155-161.

24 Jacobs, R. D. (1995) 'Exploring the determinants of cable television subscriber satisfaction', Journal of
Broadcasting \& Electronic Media, Vol. 39, spring, pp. 262-274.

25 James, M. L., Wotring, C. E. and Forrest, E. J. (1995) 'An exploratory study of the perceived benefits of electronic bulletin board use and their impact on other communication activities', Journal of Broadcasting \& Electronic Media, Vol. 39, winter, pp. 30-35.

26 LaRose, R. and Atkin, D. J. (1992) 'Audiotext and the re-invention of the telephone as a mass medium', Journalism Quarterly, Vol. 69, summer, pp. 413-421.

27 Lin, C. A. (1993) 'Modeling the gratification-seeking process of television viewing', Human Communication Research, Vol. 20, December, pp. 224-244.

28 Lin and Jeffres (1998) op. cit.

29 Perse, E. M. and Dunn, D. G. (1998) 'The utility of home computers and media use: Implications of multimedia and connectivity', Journal of Broadcasting E Electronic Media, Vol. 42, fall, pp. 435-456.

30 Sparkes, V. (1983) 'Public perception of and reaction to cable television service', Journal of Broadcasting, Vol. 27, summer, pp. 163-175.

31 Atkin, D. J. and LaRose, R. (1994) 'An analysis of the information services adoption literature', in Hanson, J. (ed.) 'Advances in telematics', Ablex, New York, pp. 91-110.

32 Dutton, W., Rogers, E. M. and Jun, S-H. (1987) 'Diffusion and social impacts of personal computers', Communication Research, Vol. 14, April, pp. 219-250.

33 Krugman (1985) op. cit.

34 Lin (1998) op. cit.

35 Rogers (1995) op. cit.

36 Ibid.

37 Atkin et al. (1998) op. cit.

38 Danko, W. D. and MacLachlan, J. M. (1983) 'Research to accelerate the diffusion of a new invention of personal computers', Journal of Advertising Research, Vol. 23, June/July, pp. 39-43.

39 Dupagne (1999) op. cit.

40 Ettema, J. S. (1984) 'Three phases in the creation of information inequities: An empirical assessment of a prototype videotex system', Journal of Broadcasting, Vol. 28, fall, pp. 383-395.

41 Litman, B., Chan-Olmsted, S. and Thomas, L. (1991) 'Estimating the demand for backyard satellite dishes: The US experience', Telematics \& Informatics, Vol. 8, spring, pp. 59-69.

42 Reagan, J. (1987) 'Classifying adopters and nonadopters of four technologies using political activity, media use and demographic variables', Telematics E Informatics, Vol. 4, spring, pp. 3-16.

43 Atkin et al. (1998) op. cit.

44 Dupagne (1999) op. cit.

45 Becker, L., Dunwoody, S. and Rafaeli, S. (1983) 'Cable's impact on the uses of other news media', Journal of Broadcasting, Vol. 27, spring, pp. 127-140.

46 Rothe, J. T., Harvey, M. G. and Michael, G. C. (1983) 'The impact of cable television on subscriber and nonsubscriber behavior', Journal of 
Advertising Research, Vol. 23, August/September, pp. 15-22.

47 Lin (1998) op. cit.

48 Jeffres and Atkin (1996) op. cit.

49 Rogers (1995) op. cit.

50 That is, the emphasis was primarily on the relationship between use of individual media and the adoption rate, while the diversity of media in general was largely ignored. The media diversity issue may become more critical as consumers are faced with more media options.

51 Lin and Jeffres (1998) op. cit.

52 Adgate, B. (2000) 'The internet's effect on traditional media',

http://www.medialifemagazine.com/features/ researchpages/ researchhorizonweb.htm, accessed 15th January, 2001.

53 Schlosberg, J. (1999) 'Report: Newspapers will be most hurt by web', Media Life Magazine, http://www.medialifemagazine.com/news1999/ sept99/news4915.html, accessed 10th January, 2001.

54 America Online (2000) 'The America Online/Roper Starch worldwide adult 2000 cyberstudy', Roper No. CNT375.

55 eMarketer (2000) 'Americans-two-fisted media users', eMarketer, 28th November, http://www.emarketer.com/estats/dailyestats/ technology/20001128_tvinternet.html?ref=wn, accessed 15th January, 2001.

56 Ettema (1984) op. cit.

57 Jeffres and Atkin (1996) op. cit.

58 LaRose and Atkin (1992) op. cit.

59 Reagan (1987) op. cit.

60 Regan (1989) op. cit.

61 Rogers (1995) op. cit., p. 15.

62 Atkin et al. (1998) op. cit.

63 Lin (1998) op. cit.

64 Dupagne (1999) op. cit.

65 Lin (1998) op. cit.

66 Larson, M. (2000) 'DBS siphons subs. Cable TV subscribers', Mediaweek, 25th September, p. 10.

67 Lin (1998) op. cit.

68 Lin and Jeffres (1998) op. cit.

69 Rogers (1995) op. cit., p. 252.

70 Ibid.

71 Atkin et al. (1998) op. cit.

72 Lin (1998) op. cit.

73 Becker et al. (1983) op. cit.

74 Ducey et al. (1983) op. cit.

75 Dupagne (1999) op. cit.

76 Jeffres and Atkin (1996) op. cit.

77 Sparkes (1983) op. cit.

78 Jacobs (1995) op. cit.

79 LaRose and Atkin (1988) op. cit.

80 Perse and Dunn (1998) op. cit.

81 Jacobs (1995) op. cit.

82 LaRose and Atkin (1991) op. cit.

83 AOL (2000) op. cit.

84 Lake, D. (2000) 'Access up, divide shrinks', The Standard, 19th June, http://www.thestandard.com/ research/metrics/display/ 0,2799,16072,00.html, accessed 10th January, 2001.
85 Rogers (1995) op. cit.

86 Moore, J. A. (1995) 'Inside the tornado', HarperCollins, New York.

87 Moore, G. A. (1999) 'Crossing the chasm', HarperCollins, New York.

88 Rogers (1995) op. cit.

89 Approximately 64 per cent of the respondents were between the ages of $18-24,16$ per cent were between the ages of 25-34, 6.4 per cent were between the ages of 35-44, 7.3 per cent were between the ages of $45-54,4.1$ per cent between the ages of 55-64 and 1.4 per cent were 65 or over. As for educational levels, about 60 per cent of the respondents are attending college and over 31 per cent of them are either attending graduate school or have postgraduate degrees. Approximately 70 per cent of the respondents are male; over 75 per cent are single. Also, about 45 per cent of the respondents had annual household income below $\$ 20,000$, and over 22 per cent had an annual income of $\$ 70,000$ or more.

90 The statements for information competency include: 1) I looked for information about cable modem before I decided to subscribe, 2) I understand the differences between cable modem and DSL, 3) I made a comparison of all high-speed Internet services before I decided to subscribe, and 4) I understand what digital TV is. The resultant Eigen value was 2.81 (total variance explained $=70.20$ per cent).

91 The statements for bundling services include: 1) I would like to receive one single bill for all telecommunications services I subscribe to, 2) I would be more likely to go to a company that can give price discounts for a package of cable TV, cable modem/Internet, and/or telephone services, and 3) I would also like to subscribe to telephone service when it is available through cable system. The resultant Eigen value was 1.62 (total variance explained $=53.93$ per cent).

92 Total variance explained by the factors was 70.11 per cent (Eigen value for the general satisfaction factor $=5.24$; Eigen value for the specific satisfaction factor $=1.07$ ).

93 Statements such as 'I like to keep up with new technologies', 'I enjoy learning to use the latest, new devices', 'I like cutting-edge, high-tech things,' 'I am willing to try new technologies', 'PCs and technology will improve the quality of my life', 'I am willing to learn new things', and 'Technology and PCs have improved my productivity' resulted in factor loadings ranging from 0.73 to 0.87 . The resultant Eigen value was 4.70 (total variance explained $=67.15$ per cent). Please contact the authors for complete results of all factor analyses.

94 Adgate (2000) op. cit.

95 Radio Advertising Bureau (2000) 'Marketing guide and factbook', Radio Advertising Bureau, Irving, Texas.

96 Television Bureau of Advertising (2000) 'Trends in television', http://www.tvb.org/tvfacts/trends/ tv/timespent.html, accessed 15th January, 2001. 
97 The variables were age $(r=0.45)$, PC tenure $(r=0.34)$, education $(r=0.33)$, magazine use $(r=0.31)$, income $(r=0.30)$ and internet tenure $(r=0.23)$. Standard tests for multicollinearity were also performed and revealed no significant problems for the regression model (all VIFs are smaller than 2).

98 An analysis of the Pearson correlation coefficients reveals this finding. The coefficients also indicated that the earlier cable modem adopters had been cable subscribers longer $(r=0.16)$, were more likely to own PDAs $(r=0.21)$, DVD $(r=0.14)$, and home theatre systems $(r=0.15)$, but were less likely to own video game players $(r=-0.14)$ and subscribe to DSL $(r=-0.18)$.

99 There may be too little variation in modem tenure to differentiate the degree of innovativeness here.

100 Multiple regression was first performed on the modem tenure variable using the five reason factors. However, the resultant adjusted $R$-square was as low as 0.05 and only the 'peer influence' factor was found to be significant. Thus, correlation analysis was performed next to describe the general relationship between modem tenure and the reason factors.

101 Correlation analysis revealed that the degrees of 'general satisfaction' $(r=-0.66, \mathrm{p}<0.01)$ and 'specific satisfaction' $(r=-0.40, p<0.01)$ were negatively related to likelihood of termination. There is also a negative relationship between the termination variable and adoption reason factors, 'system-oriented utilities' $(r=-0.28, p<0.01)$, 'Innovativeness/productivity', $(r=-0.28, p<0.01)$, 'peer influence' $(r=-0.22, p<0.01)$ and 'value and service' $(r=-0.45, p<0.01)$. The 'content-oriented utilities' factor, which includes subscription reasons such as fast download of music/video, was not a statistically significant factor in impacting the likelihood of service termination. 'Interest toward bundling service' as well as all characteristic variables were all unrelated to the termination variable. Nor was a statistically significant relationship between cable modem tenure and termination likelihood found. See Tables 3 and 4 for correlation coefficients between termination and individual adoption reasons/satisfaction variables.

102 Multiple regression was first performed on the satisfaction variable using the characteristic variables. However, the resultant adjusted $R$-square was as low as 0.06 and only 'education' was found to be significant $(\beta=-0.25)$. Thus, correlation analysis was performed next to describe the general relationship between satisfaction and the characteristic variables. Nor were any significant correlations between other characteristic variables and modem tenure with any satisfaction variables found (see Table 4).

103 These were system-oriented utilities $(r=0.40$, $p<0.01)$, innovativeness/productivity $(r=0.22$, $p<0.01)$, peer influence $(r=0.26, p<0.01)$, and value and service $(r=0.56, p<0.00)$. The factor of content-oriented utilities was not significant. Though satisfaction also correlates with information competency $(r=-0.31, p<0.01)$, a simple regression of the variable only yielded an adjusted $R$-square of 0.09 . Thus, it is not discussed further in the text.

104 Atkin et al. (1998) op. cit.

105 Rogers (1995) op. cit.

106 Ibid. 